Syntax Literate: Jurnal Ilmiah Indonesia p-ISSN: 2541-0849

e-ISSN: 2548-1398

Vol. 5, No. 8, Agustus 2020

\title{
PEMANFAATAN LAPANGAN RUMPUT SEBAGAI SARANA \\ PEMBELAJARAN SISWA KELAS VII MELALUI METODE DISCOVERY LEARNING PADA MATERI KLASIFIKASI MAKHLUK HIDUP DI SMP YABUJAH SEGERAN INDRAMAYU
}

\section{Miftahul Fatah}

Sekolah Tinggi Keguruan dan Ilmu Pendidikan (STKIP) Pangeran Dharma Kusuma Indramayu, Indonesia

Email: miftahh1979@gmail.com

\section{Abstract}

This research is motivated by a phenomenon that the use and use of instructional media can influence the learning achievements of biological science. Based on the average value at the end of each cycle of learning activities that use discovery learning models, there is an increase in the learning outcomes of the cognitive domain of science VII graders of Yabujah Segeran Indramayu Middle School. The increase in the average grade of 5.56, from 76.38 in the first cycle to 81.84 in the second cycle. The percentage of the number of students who achieved the KKM score or was declared complete learning also increased by $23.28 \%$, from $61.53 \%$ in the first cycle to $84.81 \%$ in the second cycle. In the first cycle, 7 students had not yet reached the KKM, while in cycle II there were only 2 students who had not yet reached the KKM. It can be said that in cycle II there was an increase of 5 students who had reached the KKM. The increase in science learning outcomes occurs very significantly in the second cycle because researchers have applied 7 components of the discovery learning model in natural science learning appropriately. The main components of discovery learning models are constructivism, asking, finding/inquiry, learning communities, modeling, reflection, and authentic assessment.

Keywords: discovery learning; science; learning outcomes

\section{Abstrak}

Penelitian ini dilatarbelakangi oleh sebuah fenomena bahwa penggunaan dan pemanfaatan media pembelajaran dapat mempengaruhi prestasi belajar IPA biologi, dalam hal ini peneliti memanfaatkan lapangan rumput menggunakan media pembelajaran discovery learningpada materi klasifikasi makhluk hidup di SMP Yabujah Segeran Indramayu. Berdasarkan nilai rata-rata di setiap akhir siklus kegiatan pembelajaran yang menggunakan model pembelajaran discovery learning, menunjukkan terjadi peningkatan hasil belajar ranah kognitif IPA siswa kelas VII SMP Yabujah Segeran Indramayu. Peningkatan nilai rata-rata kelas sebesar 5,56, dari 76,38 pada siklus I menjadi 81,84 pada siklus II. Persentase jumlah siswa yang mencapai nilai KKM atau dinyatakan tuntas belajar juga terjadi peningkatan sebesar $23,28 \%$, dari $61,53 \%$ pada siklus I menjadi $84,81 \%$ pada siklus II. Pada siklus I terdapat 7 siswa yang belum mencapai KKM, sedangkan pada siklus II 
tinggal 2 siswa yang belum mencapai KKM. Dapat dikatakan bahwa pada siklus II ada kenaikan 5 siswa yang telah mencapai KKM. Peningkatan hasil belajar IPA terjadi sangat signifikan pada siklus II karena peneliti telah menerapkan 7 komponen model pembelajaran discovery learningdalam pembelajaran IPA secara tepat. Komponen utama model pembelajaran discovery learningyaitu konstruktivisme, bertanya, menemukan/inkuiri, masyarakat belajar, pemodelan, refleksi, dan penilaian autentik.

Kata kunci : discovery learning; IPA; hasil belajar

\section{Pendahuluan}

Pendidikan adalah investasi sumber daya manusia jangka panjang yang mempunyai nilai strategis bagi kelangsungan peradaban manusia di dunia. Oleh sebab itu, hampir semua negara menempatkan variabel pendidikan sebagai sesuatu yang penting dan utama dalam konteks pembangunan bangsa dan negara. Begitu juga Indonesia menempatkan pendidikan sebagai sesuatu yang penting dan utama melalui proses belajar (Kunandar, 2011).

Arsyad menyampaikan pesan atau informasi dalam proses belajar mengajar dapat merangsang perhatian dan minat siswa dalam belajar (Azhar, 2013). Upaya yang dapat dilakukan oleh guru dalam proses belajar mengajar adalah menggunakan model dan media (Lisa, 2019).

Pembelajaran merupakan suatu sistem, yang terdiri atas berbagai komponen yang saling berhubunga satu dengan yang lain. Komponen ersebut meliputi: tujuan, materi, metode dan evaluasi. Keempat komponen pembelajaran tersebut harus diperhatikan oleh guru dalam memilih dan menentukan metode pembelajaran apa yang akan digunakan dalam kegiatan belajar (Rusman, 2011). Namun kenyataan umum yang dapat dijumpai di sekolah menunjukkan bahwa belum mencapai tujuan tersebut. Akibatnya siswa kurang berminat untuk mengikuti pelajaran, karena siswa merasa bosan dan tidak tertarik sehingga tidak ada motivasi dari dalam dirinya untuk berusaha memahami apa yang diajarkan oleh guru, sehingga proses belajar mengajar menjadi tidak efektif (Syah, 2012).

Hasil belajar dapat dilihat dan di ukur, pengukuran hasil belajar biasanya dilakukan dengan menggunakan butir soal baik itu berupan soal cois maupun soal pilihan ganda. Keberhasilan dalam proses belajar dapat dilihat dari hasil belajarnya (Sumantri, 2014).

Indikator hasil belajar siswa yang utama adalah ketercapaian daya serap terhadap bahan pembelajaran yang di ajarkan, baik secara individu maupun secara kelompok. Pengukuran ketercapaain daya serap ini biasanya dilakukan dengan penetapan kriteria ketuntasan belajar minimal (KKM) (Darmadi, 2017).

Hasil belajar siswa SMP Yabujah Segeran Indramayu masih belum mencapai target, terutama hasil dari mata pelajaran IPA. Hal ini terlihat dari hasil nilai ulangan kenaikan kelas. Khususnya kelas 7 yang naik kelas 8 memperoleh rata-rata nilai 5,30. Adapun nilai pelajaran biologi juga masih jauh dari harapan. Rata-rata nilai ulangan 
harian dari pokok bahasan klasifikasi makhluk hisup adalah 6,80. Dari 21 siswa ternyata yang tuntas belajar hanya 15 sedang lebihnya belum tuntas.

Kondisi hasil belajar yang sangat memprihatinkan ini perlu segera ditangani. Tentunya tidak mudah menangani masalah seperti ini, karena menyangkut berbagai pihak diantaranya ialah kurikulum, sistem evaluasi, sarana dan prasarana pembelajaran, proses belajar mengajar, siswa, guru, sekolah, dan orang tua siswa. Pihak sekolah bertanggung jawab atas penyediaan sarana dan prasarana yang menunjang proses belajar mengajar dan berbagai kebijakan yang dapat menciptakan iklim belajar yang kondusif.

Model pembelajaran merupakan salah satu komponen utama dalam menciptakan suasana belajar yang aktif,inovatif dan kreatif serta menyenangkan.Model pembelajaran yang yang menarik dan variatif akan berimplikasi pada minat maupun motivasi peserta didik dalam mengikutiproses belajar mengajar dikelas.

Menurut (Suryosubroto, 2009) metode penemuan (discovery learning) diartikan sebagai prosedur mengajar yang mementingkan pengajaran, perseorangan, manipulasi obyek dan percobaan, sebelum sampai kepada generalisasi. Sehingga metode penemuan (discovery learning) merupakan komponen dari praktik pendidikan yang meliputi metode mengajar yang memajukan cara belajar aktif, berorientasi pada proses, mengarahkan sendiri, mencari sendiri, dan reflektif. Langkah-langkah metode discovery learningadalah pemberian rangsangan, identifikasi masalah, pengumpulan data, pengolahan data, pembuktian, menarik kesimpulan.

Dalam pembelajaran discovery (penemuan), kegiatan atau pembelajaran yang dirancang sedemikian rupa, sehingga siswa dapat menemukan konsep-konsep dan prinsip-prinsip melalui proses mentalnya sendiri (Sukardi, Wigati, \& Masripah, 2015). Dalam menemukan konsep, siswa melakuakn pengamatan, menggolongkan, membuat dan sebagainya untuk menemukan beberapa konsep atau prinsip (Cahyo, 2012).

\section{Metode Penelitian}

Metode penelitian yang digunakan adalah kualitatif deskriptif. Karena penelitiannya dilakukan pada kondisi yang alamiah (natural). Selain itu data hasil peneliti lebih berkenaan dengan interptetasi yang ditemukan di lapangan. Menurut (Moleong, 2019) penelitian kualitatif adalah prosedur penelitian yang menghasilkan data deskriptif berupa kata-kata tertulis atau lisan dari orang-orang dan perilaku yang dapat diamati.

Pemilihan pendekatan ini berdasarkan permasalahan bahwa permasalahan yang diangkat penilaian analisis bahan ajar buku teks IPA yang membutuhkan data lapangan yang bersifat aktual dan kontekstual. Selain itu didasarkan pada keterkaitan masalah yang dikaji dari subjek penelitian guna mengungkap wacana kualitas buku dalam tingkat akomodasi pendekatan saintifik kurikulum 2013.

Dalam penelitian ini variabel bebasnya (X) adalah Pemanfaatan Lapangan Rumpun sebagai sarana Pembelajaran Melalui Metode Pembelajaran Discovery Learning. Sedangkan variabel dependen (Y) adalah Untuk Meningkatkan Hasil Belajar 
Siswa pada Materi Klasifikasi mahkluk hidup. Sampel dalam penelitian ini adalah peserta didik kelas VII yang terdiri dari 25 siswa.

\section{Hasil dan Pembahasan}

Hasil pengamatan menunjukkan data hasil belajar siswa ranah kognitif mata pelajaran IPA kelas VII A SMP Yabujah Segeran Indramayu Kabupaten Indramayu masih rendah. Hal ini terlihat dari nilai ulangan harian siswa. Nilai rata- rata kelas pra tindakan adalah 65 padahal KKM IPA adalah 70. Nilai rata-rata kelas untuk pembelajaran IPA tersebut masih di bawah KKM. Siswa yang nilainya sudah mencapai KKM baru sebanyak 5 siswa atau 23,80\%. Sedangkan siswa yang nilainya belum mencapai KKM sebanyak 16 siswa atau 76,19\%. Nilai terendah yang diperoleh siswa adalah 61 sedangkan nilai tertinggi yang diperoleh siswa adalah 71 . Untuk lebih jelasnya dapat disajikan tabel di bawah ini.

Tabel 1

Distribusi Frekuensi Hasil Tes IPA Pra Tindakan

\begin{tabular}{cccc}
\hline No & Nilai & Frekuensi & Persen \\
\hline 1. & 61 & 1 & 4,76 \\
2. & 62 & 2 & 9,52 \\
3. & 63 & 3 & 14,28 \\
\hline 4. & 64 & 5 & 23,8 \\
$\mathbf{5 .}$ & 65 & 4 & 19,04 \\
$\mathbf{6 .}$ & 67 & 1 & 4,76 \\
\hline 7. & 70 & 4 & 19,04 \\
8. & 71 & 1 & 4,76 \\
\multicolumn{2}{c}{ Total } & 21 & 100 \\
\hline
\end{tabular}

Tabel 2

Kriteria Hasil Tes IPA Pra Tindakan Skor

\begin{tabular}{cccc}
\hline Skor & Kriteria & Jumlah & Persentase \\
\hline $\mathbf{8 6 - 1 0 0}$ & Amat Baik & 0 & $0 \%$ \\
$\mathbf{7 6}-\mathbf{8 5}$ & Baik & 0 & $0 \%$ \\
$\mathbf{6 6}-\mathbf{7 5}$ & Cukup & 6 & $28,56 \%$ \\
$\mathbf{5 1}-\mathbf{6 5}$ & Kurang & 15 & $71,4 \%$ \\
$\leq \mathbf{5 0}$ & Gagal & 0 & $0 \%$ \\
\hline
\end{tabular}

Berdasarkan tabel di atas, dapat dilihat bahwa nilai siswa berada pada kriteria gagal $(\leq 50)$ sejumlah 0 siswa. Siswa yang mencapai kriteria kurang (51-65) sejumlah 15 siswa atau sekitar 71,4\%. Siswa yang mencapai kriteria cukup (66-75) sejumlah 6 siswa atau $28,56 \%$. Kriteria baik (76-85) berjumlah 0 siswa atau $0 \%$ dan baru ada siswa yang mencapai nilai dengan kriteria amat baik (86-100) sejumlah 0 siswa atau $0 \%$.

Pengamatan terhadap tindakan siklus I dilakukan observer yang meliputi aktivitas guru dan siswa. Pengamatan dilakukan selama proses pembelajaran berlangsung sampai 
pembelajaran selesai. Hasil pengamatan terhadap aktivitas guru di siklus I menunjukkan bahwa guru belum sepenuhnya melaksanakan model pembelajaran discovery learning dengan baik. Guru belum memberikan kesempatan kepada siswa untuk menceritakan pengalamannya yang relevan secara maksimal dengan materi di tahap konstruktivisme. Artinya, guru belum mengaitkan materi pelajaran dengan pengalaman siswa dalam kehidupan sehari-hari yang merupakan inti dari pembelajaran discovery learning. Guru belum memberi kesempatan kepada setiap siswa untuk menjawab pertanyaan yang diajukan oleh guru. Guru juga belum berhasil mengarahkan siswa untuk aktif bertanya dan menanggapi presentasi kelompok lain.

Kerja kelompok belum berjalan dengan baik karena guru tidak membimbing siswa melakukan pembagian tugas pada setiap anggota kelompok. Hasil pengamatan terhadap aktivitas siswa pada siklus I menunjukkan bahwa belum ada siswa yang menceritakan pengalamannya yang berhubungan dengan materi yang dipelajari. Siswa masih mengalami kesulitan dalam melakukan kegiatan eksperimen. Hal ini dikarenakan siswa belum memahami penjelasan guru tentang langkah kegiatan observasi. Ketika guru menjelaskan masih ada siswa yang bermain sendiri dan tidak memperhatikan penjelasan guru dengan baik. Kerja kelompok belum berjalan dengan baik karena masih ada siswa yang pasif dalam diskusi bahkan ada yang asyik bermain atau berbicara sendiri dengan temannya. Siswa masih malu untuk bertanya dan mempresentasikan hasil diskusinya. Dan siswa masih mengalami kesulitan dalam menyimpulkan hasil kegiatan eksperimen yang dilakukan. Beberapa kekurangan pada siklus I tersebut menyebabkan hasil belajar siswa ranah kognitif belum maksimal.

Tabel 3

\begin{tabular}{cccc}
\multicolumn{4}{c}{ Distribusi Frekuensi Hasil Tes Siklus I } \\
\hline No. & Nilai & Frekuensi & Persen \\
\hline 1. & 53 & 2 & $7,69 \%$ \\
\hline 2. & 60 & 1 & $3,84 \%$ \\
3. & 67 & 4 & $15,38 \%$ \\
\hline 4. & 73 & 5 & $19,23 \%$ \\
\hline 5. & 80 & 7 & $26,92 \%$ \\
\hline 6. & 87 & 4 & $15,92 \%$ \\
7. & 93 & 3 & $11,53 \%$ \\
\hline & Total & 26 & $100 \%$ \\
\hline
\end{tabular}

Berdasarkan tabel 3, dapat dilihat siswa yang sudah mencapai KKM sebanyak 14 siswa $(54,37 \%)$ dan siswa yang belum mencapai KKM sebanyak 12 siswa (45,63\%). Nilai rata-rata kelas pada siklus I adalah 76,38. Nilai tertinggi yang diperoleh siswa adalah 93 dan nilai terendah 53. 
Tabel 4

Kriteria Hasil Tes IPA Siklus I

\begin{tabular}{cccc}
\hline Skor & Kriteria & Jumlah & Persentase \\
\hline $\mathbf{8 6 - 1 0 0}$ & Amat Baik & 6 & $23,07 \%$ \\
$\mathbf{7 6 - 8 5}$ & Baik & 7 & $26,92 \%$ \\
$\mathbf{6 6}-\mathbf{7 5}$ & Cukup & 9 & $34,61 \%$ \\
$\mathbf{5 1 - \mathbf { 6 5 }}$ & Kurang & 4 & $15,38 \%$ \\
$\mathbf{5 5 0}$ & Gagal & 0 & $0,00 \%$ \\
\hline
\end{tabular}

Berdasarkan tabel 4 di atas, rata-rata nilai siswa masih terletak pada kategori cukup (66-75) sebesar 34,61\%.

Tabel berikut ini merupakan kekurangan yang masih ditemui pada siklus I dan perencanaan yang dilakukan pada siklus II.

Tabel 5 Kekurangan yang masih ditemui pada siklus I dan perencanaan yang dilakukan pada siklus II

\begin{tabular}{|c|c|}
\hline Refleksi Siklus I & Rencana Perbaikan \\
\hline $\begin{array}{l}\text { Guru belum banyak memberi } \\
\text { kesempatan siswa untuk menceritakan } \\
\text { pengalamannya yang dapat dikaitkan } \\
\text { dengan materi yang akan dipelajari } \\
\text { untuk membangun pengetahuan baru } \\
\text { siswa.(konstruktivisme). }\end{array}$ & $\begin{array}{l}\text { Siswa diberi kesempatan Menceritakan } \\
\text { pengalamannya yang berkaitan dengan } \\
\text { materi peristiwa alam dan bencana } \\
\text { alam. (konstruktivisme) }\end{array}$ \\
\hline $\begin{array}{l}\text { Guru belum memberi kesempatan } \\
\text { merata kepada setiap siswa untuk } \\
\text { menjawab pertanyaan. (bertanya) }\end{array}$ & $\begin{array}{l}\text { Siswa diberi giliran bertanya dan } \\
\text { menjawabpertanyaan secara berurutan. } \\
\text { (bertanya) }\end{array}$ \\
\hline $\begin{array}{l}\text { Guru belum membimbing siswa } \\
\text { melakukan pembagian tugas pada } \\
\text { setiap anggota kelompok masih ada } \\
\text { beberapa siswa yang pasif dan bermain } \\
\text { sendiri. (masyarakat belajar) }\end{array}$ & $\begin{array}{l}\text { Siswa dibimbing dalam Melakukan } \\
\text { pembagian tugas dalam kerja kelompok } \\
\text { agar tidak ada siswa yang pasif dan } \\
\text { bermain sendiri.(masyarakat belajar) }\end{array}$ \\
\hline $\begin{array}{l}\text { Siswa belum melakukan eksperimen } \\
\text { dengan baik karena belum memahami } \\
\text { langkah observasi. (pemodelan) }\end{array}$ & $\begin{array}{l}\text { Guru Menjelaskan petunjuk praktikum } \\
\text { dengan lebih jelas dan siswa dilibatkan } \\
\text { dalam demonstrasi penyusunan serta } \\
\text { penggunaan alat. (pemodelan) }\end{array}$ \\
\hline $\begin{array}{l}\text { Kerja kelompok atau diskusi belum } \\
\text { berjalan dengan baik. Masih terdapat } \\
\text { beberapa siswa yang pasif dan asyik } \\
\text { bermain sendiri ketika diskusi } \\
\text { kelompok. Bahkan ada kelompok yang } \\
\text { menyerahkan pekerjaan kepada satu } \\
\text { siswa saja.(inkuiri) }\end{array}$ & $\begin{array}{l}\text { Memberi motivasi kepada siswa yang } \\
\text { pasif dengan memberikan pertanyaan } \\
\text { pancingan agar lebih aktif, sehingga } \\
\text { diskusi menjadi hidup.Siswa yang aktif } \\
\text { berdiskusi diharapkan menguasai materi } \\
\text { percobaan dan mendapatkan konsep } \\
\text { IPA dengan betul.(inkuiri) }\end{array}$ \\
\hline $\begin{array}{l}70 \text { Siswa masih malu menyampaikan } \\
\text { pendapat dan tanggapan terhadap } \\
\text { kegiatan yang dilakukan. (refleksi) }\end{array}$ & $\begin{array}{l}\text { Setiap kelompok diberi kesempatan } \\
\text { untuk menyampaikan pendapatnya } \\
\text { (refleksi) }\end{array}$ \\
\hline
\end{tabular}


Kegiatan pembelajaran pada siklus II sudah menunjukkan peningkatan terhadap aktivitas siswa dan guru. Hal ini memberi pengaruh terhadap hasil belajar siswa. Pada siklus II, telah terjadi peningkatan hasil belajar siswa dilihat dari hasil tes siklus II yang meningkat dibandingkan hasil tes pra tindakan dan hasil tes siklus I. Demikian juga persentase pencapaian KKM pada siklus II juga mengalami peningkatan.

Tabel 6

\begin{tabular}{|c|c|c|c|}
\hline \multicolumn{4}{|c|}{ Distribusi Frekuensi Hasil Tes Siklus } \\
\hline No. & Nilai & Frekuensi & Persen \\
\hline 1. & 53 & 2 & $7,69 \%$ \\
\hline 2. & 73 & 2 & $7,69 \%$ \\
\hline 3. & 80 & 10 & $38,46 \%$ \\
\hline 4. & 87 & 7 & $26,92 \%$ \\
\hline 5. & 93 & 4 & $15,38 \%$ \\
\hline \multicolumn{2}{|c|}{ Total } & 26 & $100 \%$ \\
\hline
\end{tabular}

Berdasarkan tabel 6 , dapat dilihat bahwa siswa yang sudah mencapai KKM $\geq 75$ sebesar $80,76 \%$ atau sebanyak 21 siswa. Sedangkan siswa yang belum mencapai KKM tinggal 5 siswa. Nilai terendah pada siklus II ini adalah 67, sementara nilai tertinggi sudah mencapai 93. Hasil belajar IPA siswa kelas VA SD Negeri Rejondani rata-rata masuk pada kriteria amat baik (86-100) yaitu sebesar $46,15 \%$.

\section{Tabel 7}

Kriteria Hasil Tes IPA Siklus II

\begin{tabular}{cccc}
\hline Skor & Kriteria & Jumlah & Persentase \\
\hline $\mathbf{8 6 - 1 0 0}$ & Amat Baik & 12 & $46,15 \%$ \\
$\mathbf{7 6 - 8 5}$ & Baik & 10 & $38,46 \%$ \\
$\mathbf{6 6}-\mathbf{7 5}$ & Cukup & 4 & $15,38 \%$ \\
$\mathbf{5 1 - \mathbf { 6 5 }}$ & Kurang & 0 & $0 \%$ \\
$\leq \mathbf{5 0}$ & Gagal & 0 & $0 \%$ \\
\hline
\end{tabular}

Berdasarkan data 7 dapat dilihat bahwa pada siklus II terjadi peningkatan pada nilai rata-rata kelas yang mencapai 81,84 . Dari data tersebut, rata-rata kelas dalam siklus II ini sudah melebihi KKM yaitu $\geq 75$. Sedangkan persentase siswa yang mencapai nilai $\mathrm{KKM} \geq 75$ minimal $75 \%$ dari jumlah siswa, juga sudah terpenuhi. Persentase siswa yang mencapai KKM sebesar 84,61\% atau sebanyak 22 siswa dari 26 siswa.

Nilai rata-rata kelas setelah dilakukan tindakan mengalami peningkatan dari kondisi awal pra tindakan 66,69 menjadi 76,38 pada siklus I dan 81,84 pada siklus II. Persentase pencapaian KKM juga mengalami peningkatan dari kondisi awal pratindakan $38,46 \%$ menjadi $61,53 \%$ pada siklus I dan $84,81 \%$ pada siklus II. d. Refleksi Hasil observasi dan hasil tes pada siklus II menunjukkan bahwa tindakan pada 
siklus II sudah berjalan sesuai dengan yang diharapkan yaitu tercapainya nilai ratarata kelas $\geq 75$ dan persentase nilai yang mencapai KKM sudah $\geq 75 \%$. Hasil yang diperoleh pada siklus II sudah memenuhi semua kriteria keberhasilan penelitian sehingga penelitian tindakan kelas ini diakhiri dan tidak perlu dilanjutkan ke siklus berikutnya.

Berdasarkan nilai rata-rata di setiap akhir siklus kegiatan pembelajaran yang menggunakan model pembelajaran discovery learning, menunjukkan terjadi peningkatan hasil belajar ranah kognitif IPA siswa kelas VII SMP Yabujah Segeran Indramayu. Peningkatan nilai rata-rata kelas sebesar 5,56, dari 76,38 pada siklus I menjadi 81,84 pada siklus II. Persentase jumlah siswa yang mencapai nilai KKM atau dinyatakan tuntas belajar juga terjadi peningkatan sebesar 23,28\%, dari 61,53\% pada siklus I menjadi $84,81 \%$ pada siklus II. Pada siklus I terdapat 7 siswa yang belum mencapai KKM, sedangkan pada siklus II tinggal 2 siswa yang belum mencapai KKM. Dapat dikatakan bahwa pada siklus II ada kenaikan 5 siswa yang telah mencapai KKM. Peningkatan hasil belajar IPA terjadi sangat signifikan pada siklus II karena peneliti telah menerapkan 7 komponen model pembelajaran discovery learning dalam pembelajaran IPA secara tepat. Komponen utama model pembelajaran discovery learning yaitu konstruktivisme, bertanya, menemukan/inkuiri, masyarakat belajar, pemodelan, refleksi, dan penilaian autentik.

Model pembelajaran Discovery learning pada siklus II lebih efektif jika dibandingkan pada siklus I karena guru telah mengaitkan antara materi pembelajaran dengan pengalaman dan lingkungan nyata di sekitar siswa. Kegiatan pembelajaran menjadi lebih bermakna dan berkesan bagi siswa, sehingga siswa lebih mudah memahami materi IPA. Kegiatan mengaitkan materi pelajaran dengan pengalaman siswa dilakukan melalui pemberian kesempatan kepada siswa untuk menceritakan pengalamannya yang terkait materi (konstruktivisme), melibatkan siswa aktif dalam pembelajaran untuk mengalami langsung/melakukan observasi (inkuiri), bekerjasama, berdiskusi dengan teman (masyarakat belajar), dan bertanya. Kegiatan pembelajaran ini membantu siswa untuk dapat menemukan sendiri makna dari materi yang dipelajari dan membangun sendiri pengetahuannya.

\section{Kesimpulan}

Terdapat perbedaan pada minat belajar siswa yang menggunakan model pembelajaran discovery learning terhadap kelas yang menggunakan model pembelajaran konvensional. Minat belajar siswa yang menggunakan model pembelajaran discovery learning menunjukkan bahwa siswa lebih menyukai partisipasi mereka dalam pembelajaran. Terdapat perbedaan pada hasil belajar siswa kelas yang menggunakan model pembelajaran discovery learning terhadap kelas yang menggunakan model pembelajaran konvensional. Hasil belajar siswa yang menggunakan pembelajaran discovery learning menunjukkan peningkatan prestasi yang siginfikan. 


\section{BIBLIOGRAFI}

Azhar, Arsyad. (2013). Media pembelajaran. In Raja Grafindo Persada.

Cahyo, A. N. (2012). Teori-Teori Belajar Mengajar. Yogyakarta: Diva Press.

Darmadi, H. (2017). Pengembangan model dan metode pembelajaran dalam dinamika belajar siswa. Yogyakarta: Deepublish.

Kunandar. (2011). Guru Profesional. Jakarta: PT Rajagrafindo Persada.

Lisa, Sri Mona. (2019). Penerapan Model Discovery Learning Pada Materi Klasifikasi Makhluk Hidup Kelas VII Di SMPN 5 Seunagan Kabupaten Nagan Raya. UIN ArRaniry Banda Aceh.

Moleong, Lexy J. (2019). Metodologi penelitian kualitatif.

Rusman. (2011). Model-Model Pembelajaran. Jakarta: Rajawali Perss.

Sukardi, Ismail, Wigati, Indah, \& Masripah, Imas. (2015). Pengaruh metode pembelajaran discovery learning terhadap hasil belajar siswa pada mata pelajaran biologi Kelas VII di MTs Patra Mandiri Plaju Palembang. Bioilmi, 1(1), 22-29.

Sumantri, Bambang. (2014). Peningkatan Kualitas Pembelajaran Pkn Melalui Model Pembelajaran Kooperatif Tipe Teams Game Tournamen (TGT) Pada Siswa Kelas III SD Negeri Pelem 2 Ngawi. Media Prestasi, 13(1).

Suryosubroto, Buang. (2009). Proses belajar mengajar di sekolah wawasan baru: beberapa metode pendukung dan beberapa komponen layanan khusus. PT Rineka Cipta.

Syah, Muhibbin. (2012). Psikologi Belajar. Jakarta: Rajawali Press. 